\title{
A REFORMA GERENCIAL DA ADMINISTRAÇÃO PUBLICA IDEALIZADA PELO MINISTRO BRESSER PEREIRA EM 1995
}

\section{Kátia Cristina de Oliveira ${ }^{1}$ Quésia Postigo Kamimura ${ }^{2}$}

Resumo: O objetivo deste artigo consiste na apreciação sobre a Reforma Administrativa da Gestão Pública idealizada em 1995 pelo Ministro da Administração e Reforma do Estado (MARE), Dr. Luiz Carlos Bresser Pereira. Os principais resultados, obtidos por meio de estudos bibliográficos demonstram que até a presente data a inovação é ditada, principalmente, pela demanda dos serviços públicos e pelos recursos cada vez mais escassos, sendo que redução da burocratização e modernização da máquina pública propostas pelo Ministro Bresser Pereira, tem como enfoque principal a organização da estrutura do Estado e consequentemente a eficiência nos serviços públicos.

Palavras-chave: Gestão. Administração. Pública. Descentralização. Eficiência.

\footnotetext{
${ }^{1}$ Mestranda no Curso Profissional de Desenvolvimento Regional da Universidade de Taubaté, Brasil. E-mail: chrysobral@yahoo.com.br.

2 Graduada em Ciências Econômicas/Doutora em Saúde Pública pela USP, professora assistente do Mestrado Acadêmico em Planejamento e Desenvolvimento Regional da Universidade de Taubaté-UNITAU, Brasil. E-mail: qkamimura@gmail.com.
} 